\title{
Calculation of Forest Potential Evapotranspiration of Okinawa in Japan Using the Penman Equation
}

\author{
Takuya Arakaki1 ${ }^{*}$, Akira Shimizu², Naoki Kabeya², Hitoshi Ikuzawa1, \\ Takanori Shimizu3, Shin'ichi Iida3 ${ }^{3}$, Hiroshi Furugen ${ }^{4}$ \\ ${ }^{1}$ Okinawa Prefecture Forest Resource Research Centre, Nago, Japan \\ ${ }^{2}$ Kyushu Research Centre, Forestry and Forest Products Research Institute, Kurokami, Japan \\ ${ }^{3}$ Forestry and Forest Products Research Institute, Tsukuba, Japan \\ ${ }^{4}$ Incorporated Okinawa Prefecture Environment Science Centre, Urazoe, Japan \\ Email: arakatky@pref.okinawa.lg.jp
}

Received 18 March 2014; revised 15 April 2014; accepted 11 May 2014

Copyright (C) 2014 by authors and Scientific Research Publishing Inc.

This work is licensed under the Creative Commons Attribution International License (CC BY). http://creativecommons.org/licenses/by/4.0/

(c) (i) Open Access

\begin{abstract}
The northern area of Okinawa Island is a unique forest area in Japan, with a distinctive ecosystem and subtropical climate. The area is a central region of forestry in Okinawa Prefecture. However, quantitative evaluation of the effects of the forest environment is inadequate. The authors began meteorological observation of this forested area to address this situation by setting up a weather station in 2009. In this study, we performed research on one of the major factors of the water cycle in forest ecosystems, evapotranspiration. We calculate seasonal changes in potential evapotranspiration through analysis of data from our weather station in 2013, because all measurement elements were assembled. To calculate potential evapotranspiration, we used the Penman equation. We found that the potential evapotranspiration in this forest area was $1170.5 \mathrm{~mm}$ in 2013 . The mean temperature in 2013 was $20.7^{\circ} \mathrm{C}$, yearly average relative humidity was $84.7 \%$, and average wind speed was $1.40 \mathrm{~m} / \mathrm{s}$. Regarding the amount of evapotranspiration in the forests of northern Okinawa Island, which has not been previously obtained, it has become possible to calculate the amount of potential evapotranspiration using the Penman equation.
\end{abstract}

\section{Keywords}

Potential Evapotranspiration, Penman Equation, Weather Station, Subtropical Region, Evergreen Forest

\footnotetext{
${ }^{*}$ Corresponding author.
}

How to cite this paper: Arakaki, T., Shimizu, A., Kabeya, N., Ikuzawa, H., Shimizu, T., lida, S. and Furugen, H. (2014) Calculation of Forest Potential Evapotranspiration of Okinawa in Japan Using the Penman Equation. Journal of Water Resource and Protection, 6, 813-820. http://dx.doi.org/10.4236/jwarp.2014.69077 


\section{Introduction}

The northern part of Okinawa Island has subtropical forests and there is currently a need to protect the natural environment of these areas. Proactive forestry practice contributing to both lumber resource production and environmental conservation against climate change is also very important. For this reason, harmonization for both protection of the natural environment (including flora and fauna) of these areas and the use of lumber resources are currently urgent issues. Although water resources form the foundation of growth and life for plants and animals in the subtropical island ecosystems of these areas, there is presently little knowledge of the current environment of these resources. There is a pressing need to grasp the state of the water environment and water cycle processes. Given these circumstances, the authors set up a weather station in these wooded areas in 2009 and began continuous weather observations, simultaneously observing forest interior microclimate for each forest type and investigating the flow of rainfall from basin areas [1] [2]. Additionally, observations of the rainfall runoff process of a small forested watershed are continuing.

The study of potential evapotranspiration using the Penman equation has been used in the field of agricultural meteorology in Japan; however, there has been little use of studies on forest evapotranspiration in this area. Additionally, most regions in the country are temperate and warm temperate, and there have been few studies of evapotranspiration in the forest environments of subtropical islands.

We focus on one of the major water cycle factors in forest ecosystems, namely, evapotranspiration. We calculate seasonal changes of potential evapotranspiration volume through analysis of weather station data from 2013. To calculate potential evapotranspiration, we used the Penman equation.

\section{Study Site and Method}

\subsection{Study Site}

The area of Okinawa (Figure 1) Island is $1208 \mathrm{~km}^{2}$ and the northern wooded areas comprise approximately half this area, or $764 \mathrm{~km}^{2}$. Forest in the region is the evergreen broad-leaved, such as Castanopsis sieboldii and Quercus miyagii. The climate is maritime subtropical. The topography features a central mountain ridge with surrounding rivers, and the land is broadly divided east and west by this ridge. The area around Mt. Nishimedake was designated an Okinawa prefectural wildlife sanctuary in 1985, and it is a forested area inhabited by ecologically important species of plants and animals endemic to the island. These include the Okinawa woodpecker (Sapheopipo noguchii) and Okinawa rail birds (Gallirallus okinawae). Accordingly, forests in this area have not been the focus of much forestry practice and are comparatively well preserved.

The weather station $\left(26^{\circ} 48^{\prime} 39^{\prime \prime} \mathrm{N}, 128^{\circ} 16^{\prime} 23^{\prime \prime} \mathrm{E}\right)$ is on flat land along the Chinufuku woodland path (elevation $300 \mathrm{~m}$ ), approximately $500 \mathrm{~m}$ north of the summit of Mt. Nishimedake, in the Kunigami area at the northern extremity of the mountain ridge. This location has been protected from surrounding tree influences, because it was on a higher plateau formed by woodland path debris. The weather station was constructed to observe weather conditions in these preserved forest areas. There had never been such a weather station in these areas, so this construction was the first of its kind. Forest in the region is evergreen broad-leaved, such as Schima wallichii and Castanopsis.

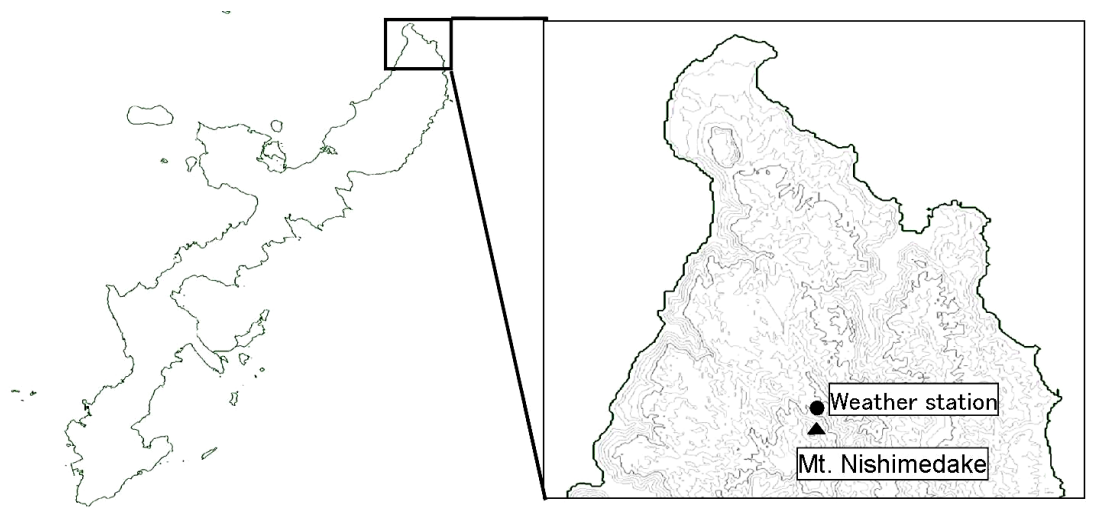

Figure 1. Weather station and Okinawa Island. 


\subsection{Weather Station}

Construction of the weather station was completed on March 17, 2009, and most weather observations began on this date. Observed weather variables from this date were solar radiation, wind direction, wind speed, temperature, humidity, and precipitation. From 2013 on, we added measurements of net radiation for calculation of Penman estimation. While updating the observation equipment and adding new variables, we continued observations through to the present (2014). Inside the weather station, there is a foundation block and tripod base fixed in place with concrete, with a pole perpendicular to it. A solar radiation measuring device (Delta OHM LP PYRA03) is on an arm extending south from this pole, and a wind direction and wind speed measuring device (MetOne 034B Windset) is attached to an arm extending north (both are approximately $3 \mathrm{~m}$ above ground). A hygrometer (Vaisala HMP-45A) is fitted with a wind shield and attached directly to the pole (1.5 m above ground). A rain gauge (UIZIN U-Dot, $0.5 \mathrm{~mm}$ sensitivity) is in an area separate from the other devices, $1.5 \mathrm{~m}$ above ground. A radiation meter (REBS Q7), added in January 2013, is at the same height as the solar radiation measuring device, on a pole extending south-southwest to ensure the two devices do not interfere with each other. All data are recorded in batch format by a data logger (Campbell CR-1000). The battery used by the data logger is recharged by a solar panel connected to the pole, and it has confirmed stable operation.

\subsection{Meteorological Elements and Penman Equation}

Potential evapotranspiration from the Penman equation is defined as "daily evapotranspiration from a water surface or thoroughly damp device, roughly the height of a rice plant”. Thus, we consider the result to be the maximum possible evapotranspiration value. In our project, we used the equation to determine possible evapotranspiration in the Okinawa Island northern wooded area, assuming that the ground surface is thoroughly damp. The aim was to find an evapotranspiration index for the region. Targeted data were observed values from the weather station in 2013. Average values of temperature $(T)$, relative humidity $(R H)$, wind speed $(u)$, and global solar irradiance $(R a d)$ were used in calculation on a daily basis. The net radiation measurements $\left(\mathrm{MJ} / \mathrm{m}^{2}\right)$ were total daily values added together. Although the Penman equation has been used in many studies, we followed that of [3] and [4] for determining potential evapotranspiration.

$$
E T_{\text {pen }}=\frac{\Delta}{\Delta+\gamma} \times \frac{S}{\ell}+\frac{\gamma}{\Delta+\gamma} \times f(u)\left(e_{s a}-e_{a}\right)
$$

$E T_{\text {pen }}$ : Penman's potential evapotranspiration (mm);

$S$ : net radiation $\left(\mathrm{MJ} \cdot \mathrm{m}^{-2}\right)$;

$\Delta$ : slope of temperature saturation water vapor pressure curve at temperature $t\left(\mathrm{hPa} /{ }^{\circ} \mathrm{C}\right)$;

$\gamma$ : psychometric constant $\left(=0.66 \mathrm{hPa} \cdot{ }^{\circ} \mathrm{C}\right)$;

$\ell$ : latent heat of water evaporation;

$\ell=2.5-0.0024 \times T$;

$f(u)\left(e_{s a}-e_{a}\right)$ : Dalton's wind function;

$f(u)=0.26(1+0.54 u)$, where $u$ is mean wind speed of the day at $3 \mathrm{~m}$ above ground $(\mathrm{m} / \mathrm{s})$;

$e_{s a}$ : saturation water vapor pressure at temperature $t(\mathrm{hPa})$.

$$
e_{\mathrm{sa}}=06.1078 \exp \left(\frac{17.2694 t}{t+237.3}\right)
$$

$e_{a}$ : water vapor pressure of air $(\mathrm{hPa})$;

$e_{a}=e_{s a} R H / 100$

$T$ : temperature $\left({ }^{\circ} \mathrm{C}\right)$;

$R H$ : relative humidity (\%).

\subsection{Method of Calculating Actual Sunshine Duration and Possible Sunshine Duration}

Monthly actual sunshine hours $(n)$ and possible sunshine duration $(N)$ were calculated as indicators of the meteorological elements in 2013. Because there was no observation equipment that could directly measure actual sunshine duration in this observation field, it was calculated as follows. To calculate $n$, direct solar radiation is required. Therefore, using the relationship between rate of global solar radiation and that of direct solar radiation 
in Naha, Okinawa, direct solar radiation was calculated by [5]. According to that work, the mean global solar radiation rate in Naha was 0.41 , and the mean direct solar radiation rate was 0.18 . Hence, the direct solar radiation was calculated by multiplying the ratio $0.4390(=0.18 / 0.41)$ and solar radiation. Among values of calculated direct solar radiation, those larger than the threshold $120 \mathrm{Wm}^{-2}$ were multiplied to calculate $n$ and $N$.

\section{Results and Discussion}

Daily averages of weather elements in each month during January-December 2013 are shown in Figures 2-7. Average temperature of each month in 2013 was $13.1^{\circ} \mathrm{C}$ in January, $16.5^{\circ} \mathrm{C}$ in February, $17.1^{\circ} \mathrm{C}$ in March, $17.4^{\circ} \mathrm{C}$ in April, $20.8^{\circ} \mathrm{C}$ in May, $25.2^{\circ} \mathrm{C}$ in June, $26.5^{\circ} \mathrm{C}$ in July, $27^{\circ} \mathrm{C}$ in August, $27^{\circ} \mathrm{C}$ in September, $26.5^{\circ} \mathrm{C}$ in October, $17.8^{\circ} \mathrm{C}$ in November, and $13.7^{\circ} \mathrm{C}$ in December. Average temperature for all of 2013 was $20.7^{\circ} \mathrm{C}$. In 2013, average temperature from July to August was relatively high, greater than $25^{\circ} \mathrm{C}$. Low-temperature patterns were observed in January, February and December (Figure 2). The highest temperature $27.4^{\circ} \mathrm{C}$ was recorded in August, and lowest $14.5^{\circ} \mathrm{C}$ in January. Average relative humidity of each month in 2013 was $79.0 \%$ in January, $78.9 \%$ in February, 83.4\% in March, 84.9\% in April, 91.6\% in May, 89.6\% in June, 86.5\% in July, 87.7\% in August, 87.4\% in September, 86.5\% in October, $81.3 \%$ in November, and 79.4\% in December. Average relative humidity for all of 2013 was $84.7 \%$. Precipitation of each month in 2013 was $306.5 \mathrm{~mm}$ in January, $221 \mathrm{~mm}$ in February, $233.5 \mathrm{~mm}$ in March, $278.5 \mathrm{~mm}$ in April, $213.5 \mathrm{~mm}$ in May, $143.5 \mathrm{~mm}$ in June, $26.5 \mathrm{~mm}$ in July, $59.5 \mathrm{~mm}$ in August, $82.5 \mathrm{~mm}$ in September, $113 \mathrm{~mm}$ in October, $29.2 \mathrm{~mm}$ in November, and $70 \mathrm{~mm}$ in December. Precipitation in 2013 was $2040.5 \mathrm{~mm}$. Mean annual precipitation for years 2010-2012 was $3424 \mathrm{~mm}$, and that of 2013 was very low. The area is believed to have over $3000 \mathrm{~mm}$ of annual precipitation. Therefore, the Penman method estimation in 2013 may be overestimated than average year value because of dried climate condition such as more fine days. Average wind speeds (m/s) of each month were 1.50 in January, 1.60 in February, 1.58 in March, 1.50 in April, 1.45 in May, 1.25 in June, 1.20 in July, 1.20 in August, 1.61 in September, 1.29 in October, 1.26 in November, and 1.41 in December. The average wind speed for all of 2013 was $1.40 \mathrm{~m} / \mathrm{s}$. Average speeds during the year were $1.2-1.6 \mathrm{~m} / \mathrm{s}$, with higher speeds observed from January through April. This trend was evident for strong westerly winds between January and March on the main island of Okinawa. Average global solar irradiance (in $\mathrm{W} / \mathrm{m}^{2}$ ) of each month was 175.5 in January, 217.7 in February, 275.2 in March, 261.2 in April, 220.5 in May, 349.1 in June, 412.9 in July, 393 in August, 287.4 in September, 195 in October, 217 in November, and 167.7 in December. The strongest solar radiation was in July, and amounts were higher from June through August. There was a tendency for smaller amounts during winter, in January and December. Upon entering the rainy season in May, global solar radiation decreased on the main island. Average actual sunshine duration of each month (in hours) was 2.7 in January, 3.7 in February, 5.1 in March, 4.7 in April, 4.0 in May, 6.7 in June, 8.2 in July, 7.7 in August, 5.6 in September, 3.3 in October, 3.5 in November, and 2.7 in December. There was a tendency toward longer actual sunshine duration between July and September. There were shorter durations from January to February, and it became shorter in May. The longest duration was 8.2 hours in July, with the shortest at 2.7 hours in January. This gives a difference of 5.5 hours between those months. Figure 8 shows accumulated values of net radiation for each month in 2013. These were (in $\mathrm{kW} / \mathrm{m}^{2}$ ): 216.6 in January, 262.7 in February, 385.3 in March, 385.6 in April, 369.4 in May, 585.6 in June, 706.1 in July, 660.4 in August, 482.9 in September, 289.3 in October, 264.4 in November, and 203.1 in December.

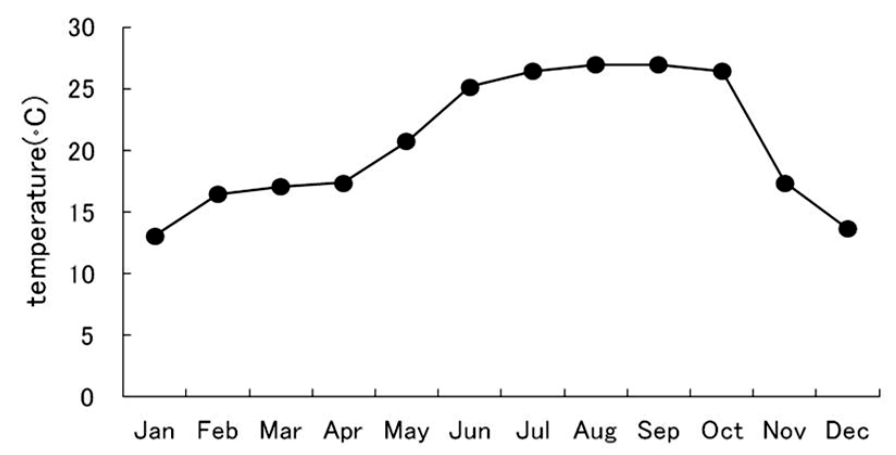

Figure 2. Average temperature of each month. 


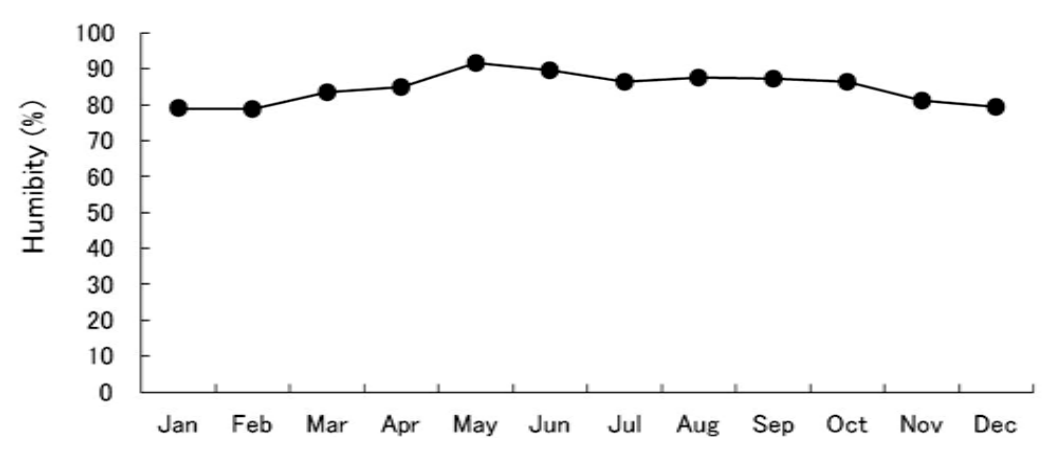

Figure 3. Average relative humidity of each month in 2013.

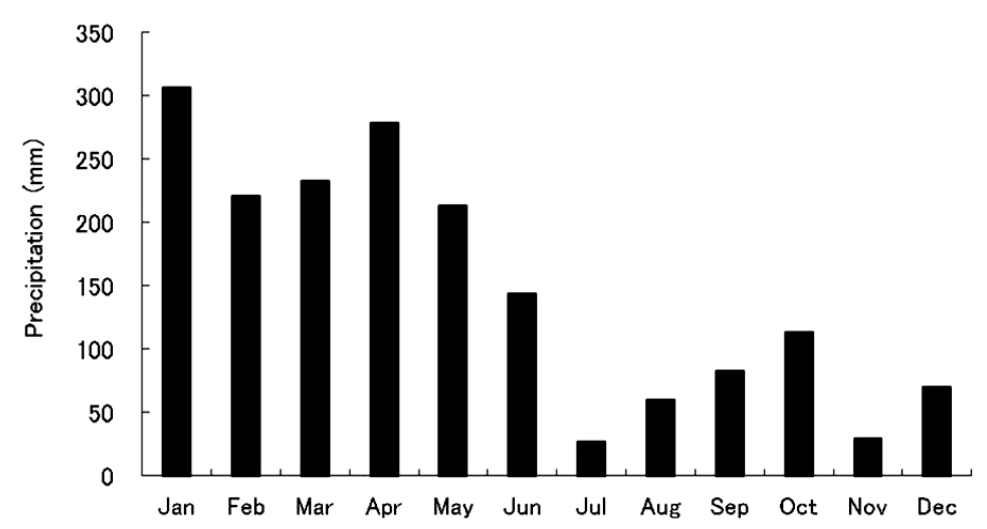

Figure 4. Precipitation of each month in 2013.

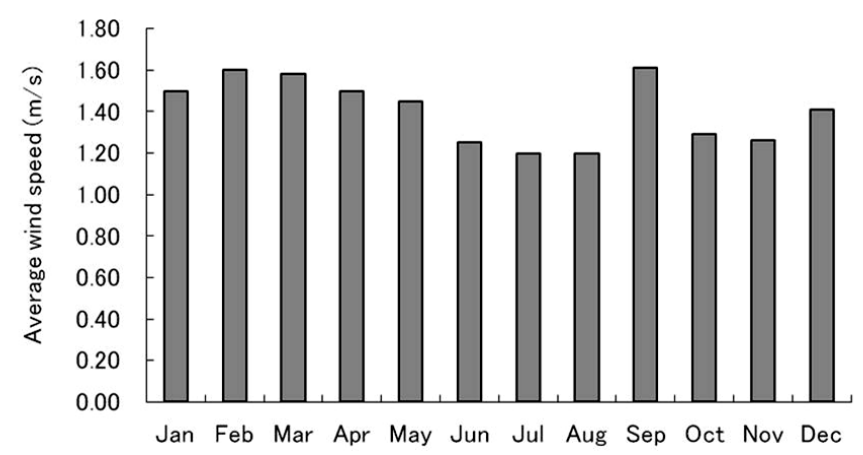

Figure 5. Average wind speeds (m/s) of each month in 2013.

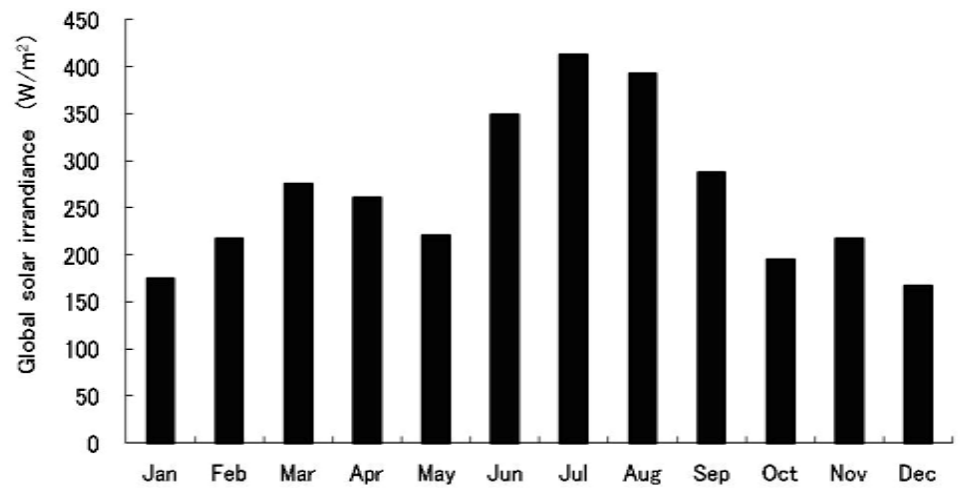

Figure 6. Average global solar irradiance (in W/m²) of each month in 2013. 


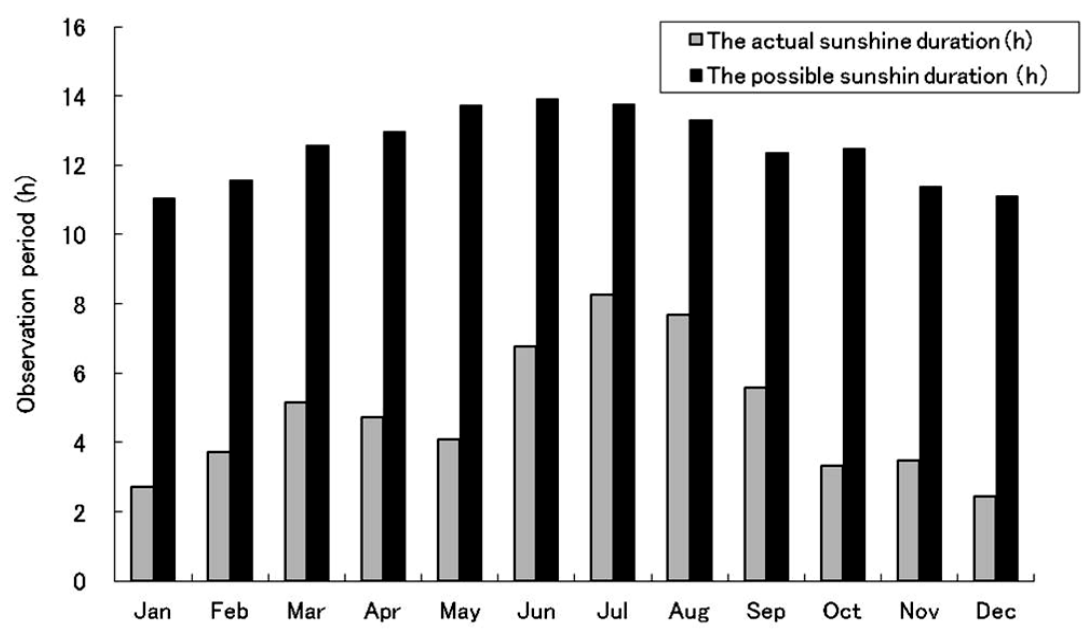

Figure 7. Average global solar irradiance (in $\mathrm{W} / \mathrm{m}^{2}$ ) of each month in 2013.

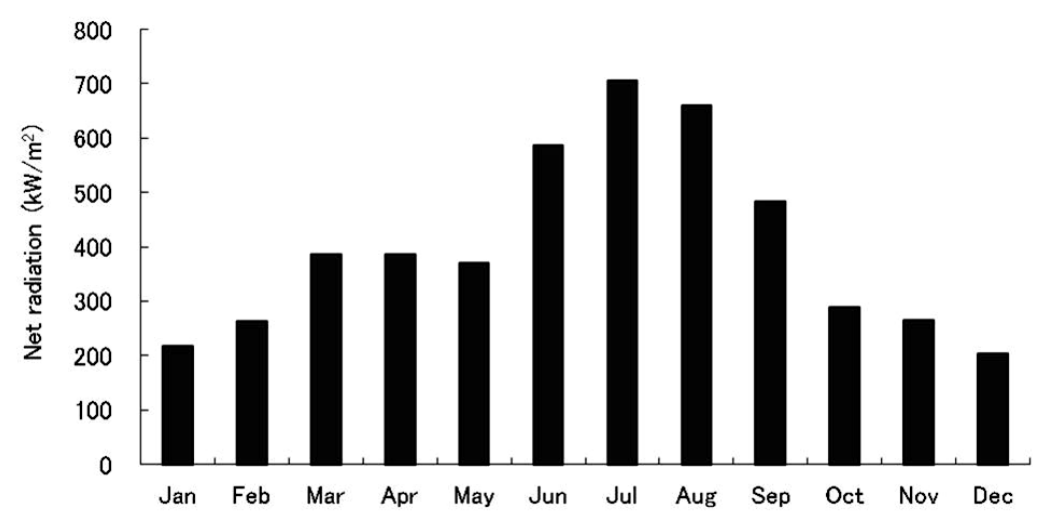

Figure 8. Accumulated values of net radiation for each month in 2013.

Figure 9 shows 2013 monthly potential evapotranspiration in a forest area of northern Okinawa Prefecture. Potential evapotranspiration per day (mm/d) of each month was 1.58 in January, 2.04 in February, 2.71 in March, 2.8 in April, 2.72 in May, 4.92 in June, 5.91 in July, 5.54 in August, 4.03 in September, 2.63 in October, 2.07 in November, and 1.49 in December. Potential evapotranspiration of each month (mm/month) was 48.8 in January, 57.1 in February, 84.1 in March, 82.9 in April, 84.1 in May, 147.7 in June, 183.2 in July, 171.8 in August, 121.1 in September, 81.4 in October, 62.3 in November, and 46 in December. Potential evapotranspiration for the year was $1170.5 \mathrm{~mm}$. In comparison with the precipitation data, the evapotranspiration estimate for August with less rain is clearly excessive. In the future, it will be necessary to accumulate the data, making a correction using a normal value. December had the least potential evapotranspiration, followed by January and November.

Potential evapotranspiration was greatest in July. [6] calculated evapotranspiration in a normal year using the Penman equation, based on observed data in Naha (using $\alpha=0.06$ ). Table 1 shows a comparison with the present results. Our values are smaller than those of Naha in any month. Potential evapotranspiration varied in similar ways in both datasets.

[7] reported on evapotranspiration amount from heat balance and water balance observation in an artificial conifer forest at Kahoku experimental watershed, in a warm temperate region of southwestern Japan. For annual amount of evapotranspiration in the basin in their study, the heat balance method using tower observation gave $\sim 900 \mathrm{~mm}$, and calculation using the water balance was $920 \mathrm{~mm}$. [8] reported on evapotranspiration amount from water balance calculations for 2010 in the same region. For their annual amount of evapotranspiration in the basin, calculation using the water balance was $1117.4 \mathrm{~mm}$. On the other hand, we obtained possible evapotranspiration from the Penman equation at $\sim 1170 \mathrm{~mm}$. It is expected that actual evapotranspiration amount on subtropical islands is greater than that in warm temperate areas, because average annual temperature and annual rainfall 
Table 1. Comparison of potential evapotranspiration per day of each month.

\begin{tabular}{ccc}
\hline Month & $\begin{array}{c}\text { Kunigami Village } \\
\text { Weather Measurement Station (2013) }\end{array}$ & $\begin{array}{c}\text { Naha City } \\
\text { Miura \& Moroizumi (2007) }\end{array}$ \\
\hline Jan & 1.58 & 2.6 \\
Feb & 2.07 & 2.9 \\
Mar & 2.71 & 3.4 \\
Apr & 2.80 & 4.1 \\
May & 2.72 & 4.5 \\
Jun & 4.92 & 5.3 \\
Jul & 5.91 & 6.4 \\
Aug & 5.54 & 5.9 \\
Sep & 4.03 & 5.3 \\
Oct & 2.63 & 4.2 \\
Nov & 2.07 & 3.2 \\
Dec & 1.49 & 2.7 \\
\hline
\end{tabular}

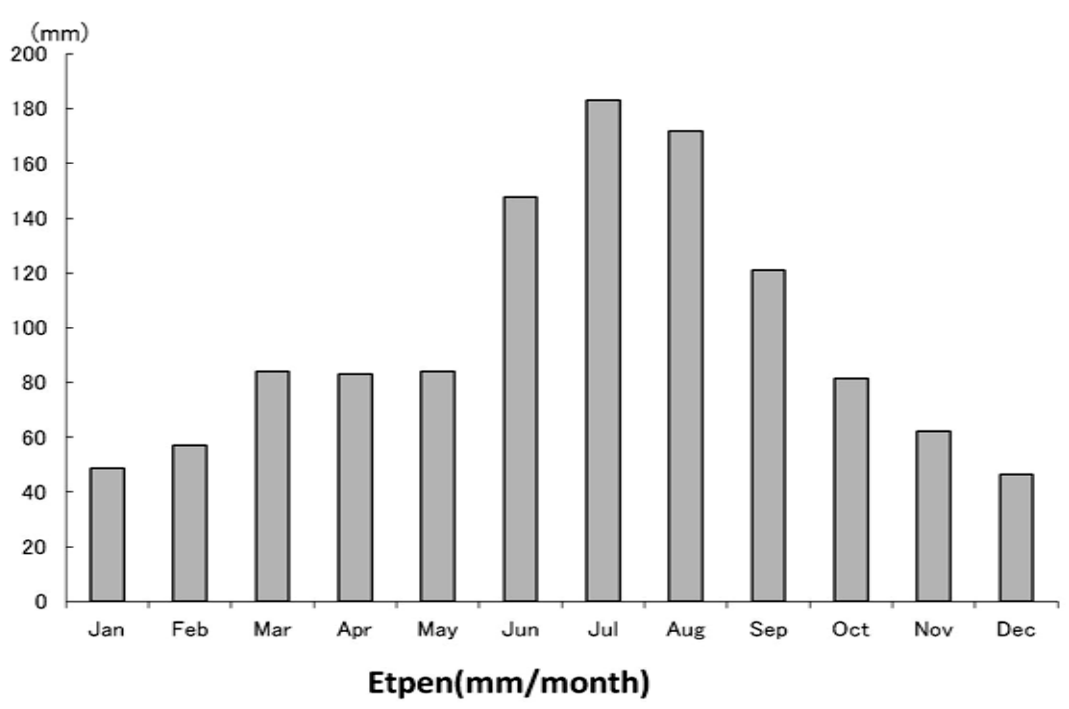

Figure 9. Potential evapotranspiration of each month (mm/month).

in the former are greater. Compared with the results of [8], potential evapotranspiration in our study was more than $50 \mathrm{~mm}$. Consequently, estimated evapotranspiration is considered largely reasonable.

The value calculated by the Penman formula is possible evapotranspiration and, as mentioned above, is considered the maximum evapotranspiration in an area. Thus, the possible evapotranspiration we calculated is considered the maximum in the northern forest of Okinawa, and will be an important index for water resource management in the future.

It has become possible to calculate the amount of potential evapotranspiration using the Penman equation and to determine the water resource by combining rainfall data in this area. A water resource index could be calculated using rainfall minus evapotranspiration. Evapotranspiration is a leading explanatory factor for water in the forest environment and is directly related to changes of soil water. Indicators developed for changes of potential evapotranspiration and total amount of potential evapotranspiration in the aforementioned Okinawan forests are expected to play a major role in forest management and biodiversity as forest environment indicators. The present study revealed that potential evapotranspiration in the studied forest area decreased during November 
through February (winter), but increased during May through September (summer). This trend is consistent with the research of [6] using the data of the Okinawa Meteorological Observatory at Naha city (2007).

\section{Conclusion}

In this study, we set up for the first time a meteorological observation field in the northern forest area of Okinawa Island, and began meteorological observations. Regarding the amount of evapotranspiration in the forests of northern Okinawa Prefecture, which has not been previously obtained, it has become possible to calculate the amount of potential evapotranspiration using the Penman equation and to determine the water resource by combining rainfall data. Potential evapotranspiration for 2013 in the northern forest area calculated by the Penman equation was $1273.1 \mathrm{~mm}$. This value is possible evapotranspiration and is considered as the maximum evapotranspiration in an area. This is more than $\sim 160 \mathrm{~mm}$ greater than evapotranspiration using the water balance method [8]. The possible evapotranspiration we calculated is considered as the maximum evapotranspiration in the northern forest area, and will be an important index for water resource management in the future. The study also showed that potential evapotranspiration in the forest decreased during November through February (winter), but increased during May through September (summer). Because the year 2013 had comparatively low precipitation, it is supposed to be necessary to accumulate more data and improve precision henceforth.

\section{References}

[1] Shimizu, T., Kabeya, N., Shimizu, A., Asano, S., Ikuzawa, H., Imada, M., Higa, M. and Furugen, H. (2011) Comparisons of Micrometeorological Factors near the Forest Floor of Variously Managed Forests in Northern Part of Okinawa Island. Kyushu Journal of Forest Research, 64, 108-109.

[2] Higa, M., Shimizu, T., Kabeya, N., Shimizu, A., Ikuzawa, H., Imada, M. and Furugen, H. (2011) Initial Data from a New Meteorological Station at a Forested Area in the Northern Part of the Mainland Okinawa. Kyushu Journal of Forest Research, 64, 102-104.

[3] Miura, T. and Okuno, R. (1993) Detailed Description of Calculation of Potential Evapotranspiration Using the Penman Equation. Transactions of the Japanese Society of Irrigation, Drainage and Reclamation Engineering, 164, 157-163.

[4] Hattori, S. (1985) Explanation on Derivation Process of Equations to Estimate Evapotranspiration and Problems on the Application to Forest Stand. Bulletin Forestry and Forest Products Research Institute, 332, 139-165.

[5] Kamii, Y., Fujimura, T. and Chikamori, K. (2001) Climatological Estimation of Solar Radiation. Research Reports of Kochi University, Natural Science, Japan, 50, 81-94.

[6] Miura, T. and Moriizumi, T. (2007) Sensitivity Analysis of the Meteorological Elements to the Penman Potential Evapotranspiration. Abstracts of the Japanese Society of Irrigation, Drainage and Reclamation Engineering, 846-847.

[7] Shimizu, A., Shimizu, T., Miyabuchi, Y. and Ogawa, Y. (2003) Evapotranspiration and Runoff in a Forest Watershed, Western Japan. Hydrological Processes, 17, 3125-3139. http://dx.doi.org/10.1002/hyp.1261

[8] Kabeya, N., Shimizu, A., Shimizu, T., Ikuzawa, H., Arakaki, T., Furugen, H., Ohnuki, Y. and Asano, S. (2014) Rainfall and Runoff Observations in the Subtropical Forest of Okinawa Island. Journal of Water Resource and Protection (JWARP), Special Issue on Evapotranspiration Call for Papers, in Press. 